\title{
Mechanical Damage Assessment of GFRP Rebars with Different Resins due to Hydrothermal Aging
}

\author{
Ruan Carlos de Araújo Moura ${ }^{a^{*}}$ (1), Daniel Véras Ribeiro ${ }^{b}$ (D), Paulo Roberto Lopes Lima ${ }^{c}$ ()ㅜ \\ ${ }^{a}$ Universidade Federal da Bahia, Programa de Pós-Graduação em Engenharia Civil (PPEC), Rua \\ Aristides Novis, 02, Federação, 40210-630, Salvador, BA, Brasil. \\ ${ }^{b}$ Universidade Federal da Bahia, Departamento de Ciência e Tecnologia dos Materiais, Rua Aristides \\ Novis, 02, Federação, 40210-630, Salvador, BA, Brasil. \\ 'Universidade Estadual de Feira de Santana, Departamento de Tecnologia, Av. Transnordestina, s/n, \\ Novo Horizonte, 44036-940, Feira de Santana, BA, Brasil.
}

Received: April 11, 2021; Revised: June 23, 2021; Accepted: July 05, 2021

\begin{abstract}
This study investigates the effect of hydrothermal aging on the properties of glass fiber reinforced polymer (GFRP) rebars manufactured with isophthalic polyester or vinylester resin and glass fiber type E. The GFRP rebars were immersed in an alkaline solution ( $\mathrm{pH} \mathrm{12.6)} \mathrm{for} 1000 \mathrm{~h}$ at different temperatures $\left(23\right.$ and $60^{\circ} \mathrm{C}$ ), and their deterioration was evaluated based on microstructural and chemical changes (using SEM, DSC, XRF, and FTIR techniques), moisture absorption, and variation in mechanical properties. The results indicated an increase in the presence of voids and water absorption of the rebars with accelerated aging, with a reduction in the glass transition temperature of the resin and alteration of the chemical composition of the glass fiber. The comparison between the experimental results indicates that the rebars with matrix in vinylester resin present greater chemical resistance than the rebars with a polyester matrix. The degradation of the rebar also resulted in a reduction of approximately $6 \%$ in the tensile strength of the rebar and $2 \%$ in the modulus of elasticity. Using the damage model, it was possible to identify that the reduction in mechanical strength was associated with the simultaneous degradation of the resin and glass fiber due to the alkaline attack.
\end{abstract}

Keywords: GFRP rebars, Durability, Polymeric matrix, Glass fiber, Alkaline environment, Environmental reduction factor.

\section{Introduction}

Reinforced concrete with steel rebars is the most widely used structural material for the construction of bridges, ports, viaducts, drainage systems, and building structures. However, corrosion of the reinforcement has been observed in many of these structures, which results in cracking of the concrete and reduction in the lifetime. Consequently, the cost of maintenance and recovery of reinforced concrete structures, associated with corrosion in steel reinforcements, is estimated to be approximately $3.5 \%$ of the Brazilian GDP ${ }^{1}$, which creates an economic problem. One of the alternatives to reduce such degradation is the replacement of steel rebars with glass fiber reinforced polymer (GFRP) rebars, mainly in major structures such as bridges, viaducts, and ports, ${ }^{2,3}$, because the GFRP rebars have greater durability than steel rebars, high specific strength and stiffness combined with low specific weight ${ }^{4}$.

GFRP rebars can be produced with different types of thermosetting resins (epoxy, polyester, or vinylester), and different types of glass fibers (E, ECR, or AR). The compatibility of the glass fibers with different resins depends mostly on the sizing (substances applied at the moment of fiber fabrication $)^{5}$. However, if the rebars are not subjected

*e-mail: ruan_moura@yahoo.com.br to an electrolytic corrosion process, they present chemical deterioration when in contact with the alkaline environment inside the concrete ${ }^{6}$, because the pore solution of the concrete is characterized by $\mathrm{pH}$ in the range of $12.5-13.5^{7}$. Environmental humidity also causes changes in the resin ${ }^{8,9}$; the main effects are plasticization and reduction in glass transition temperature, strength, and rigidity ${ }^{10}$.

The degradation of GFRP rebars occurs owing to a complex physical-chemical process that damages the polymeric matrix and causes dissolution of the glass fibers, resulting in changes in their physical, chemical, thermal, and mechanical properties. Hydroxyl $\left(\mathrm{OH}^{-}\right)$ions, which are present in the pore solution of the concrete as a result of the dissolution of the hydroxides of the cementitious matrix $\left(\mathrm{NaOH}, \mathrm{Ca}(\mathrm{OH})_{2}\right.$, and $\left.\mathrm{KOH}\right)$, penetrate the polymeric matrix of the GFRP rebars by diffusion, causing a hydrolysis reaction of the ester groups (present in polyester and vinylester matrices). The result of this process is the decomposition of the matrix of the GFRP rebar ${ }^{11}$, which allows the glass fibers to be exposed to the alkaline solution ${ }^{12,13}$. These damaging effects on GFRP rebars have been reported in some recent studies. Sawpan ${ }^{14}$ subjected GFRP rebars, manufactured with vinylester matrix, to an alkaline environment $(\mathrm{pH}=12.0)$ at temperatures of $23^{\circ} \mathrm{C}$ and $60{ }^{\circ} \mathrm{C}$, and found a reduction in tensile strength of $9 \%$ and $26 \%$, when compared to GFRP 
rebars without aging. Fergani et al. ${ }^{6}$ reported a reduction between $6 \%$ and $36 \%$ in the tensile strength of GFRP rebars subjected to a similar aging process. Ali et al. ${ }^{15}$ subjected GFRP rebars with polyester matrix to an alkaline environment $\left(\mathrm{pH}=12.8\right.$ ) at temperatures of $23{ }^{\circ} \mathrm{C}, 40^{\circ} \mathrm{C}$, and $60{ }^{\circ} \mathrm{C}$, and observed a reduction in tensile strength of $5 \%, 12 \%$, and $14 \%$, respectively. Benmokrane et al. ${ }^{16}$ evaluated the mechanical behavior of GFRP rebars manufactured with vinylester, polyester, and epoxy resin matrices. The authors found that GFRP rebars with polyester and epoxy resin matrices had a similar reduction in flexural strength $(25 \%$ and $23 \%$, respectively) after $5000 \mathrm{~h}$ of immersion, while the GFRP rebars with vinylester matrix had a lower reduction of $17 \%$. Thus, it is confirmed that the type of resin used affects the durability of GFRP rebars to different levels.

Currently, the design standards for concrete structures reinforced with FRP rebars specify that the tensile strength of the GFRP rebar, used in the design equations must be reduced based on the type and level of environmental exposure. According to ACI 440.3R-15 ${ }^{17}$, the environmental reduction factor used in the correction of tensile strength and ultimate deformation is determined by considering the type of fiber and the exposure of the structure to the earth and weather. To determine the environmental correction factor, the normative recommendation CNR-DT $203^{10}$ indicates the following factors: the type of fiber, exposure condition, and type of resin used in the FRP rebar (which can be epoxy or vinylester resin). However, this normative recommendation also does not consider the type of resin used to determine the environmental correction factor, despite the fundamental role of the resin in the durability of FRP ${ }^{18}$.

The present research aims to evaluate the effect of hydrothermal aging in GFRP rebars manufactured with two different types of polymeric matrices (isophthalic polyester or vinylester). The GFRP rebars were immersed in an alkaline solution ( $\mathrm{pH}$ 12.6) for $1000 \mathrm{~h}$ at two temperatures $\left(23{ }^{\circ} \mathrm{C}\right.$ and $60{ }^{\circ} \mathrm{C}$ ) to accelerate the effects. Subsequently, the rebar properties (physical, chemical and mechanical) were assessed and compared with the values obtained for the unconditioned reference samples. The tensile strength of the GFRP rebars after aging was theoretically evaluated by applying the damage mechanic to the mixture rule and comparing it with the experimental data.

\section{Materials and Methods}

\subsection{Materials}

The GFRP rebars were produced by the pultrusion process which involves a machine pulling the glass fiber through a liquid resin (polyester resin or vinylester resin) and then pulling that combination of glass fiber and resin through a cylindric die. After that, the rebar through a mechanism rotating to the axis, to create the ribs. Subsequently, the rebar is heated and cut ${ }^{19}$.

The pultruded GFRP rebars used in this study had a nominal diameter of $12.7 \mathrm{~mm}$, and were made of continuous E-glass fibers impregnated in two types of polymeric resin. In the first type of GFRP rebar, isophthalic polyester resin (GFRP P) was used, and vinylester resin (GFRP V) was used as the second type. Surface enhancement consisted of a simple, helically-fiber-wrapped (Figure 1). The physical properties of the GFRP rebars and the corresponding ASTM standard procedures are summarized in Table 1. Both types of GFRP rebars had similar mass fractions of glass fibers.

\subsection{Accelerated aging procedure}

Hydrothermal aging was performed by immersing the rebars in alkaline solutions $(\mathrm{pH}=12.6)$ at temperatures of $23{ }^{\circ} \mathrm{C}$ and $60{ }^{\circ} \mathrm{C}$ for $1000 \mathrm{~h}$. The solution was composed of $118.5 \mathrm{~g}$ of calcium hydroxide, $\mathrm{Ca}(\mathrm{OH})_{2}, 0.9 \mathrm{~g}$ of sodium hydroxide, $\mathrm{NaOH}$, and $4.2 \mathrm{~g}$ of potassium hydroxide, $\mathrm{KOH}$, dissolved in $1 \mathrm{dm}^{3}$ of deionized water, according to ACI 440.3R-15 ${ }^{17}$ and ASTM D7705 ${ }^{23}$ standards. To maintain a uniform temperature, one of the containers was kept in an air-conditioned room at $23{ }^{\circ} \mathrm{C}$, and the other container was kept in a furnace previously heated to $60{ }^{\circ} \mathrm{C}$. For this test, three samples of GFRP rebars, with $46.0 \mathrm{~cm}$ of length, were used for each temperature.

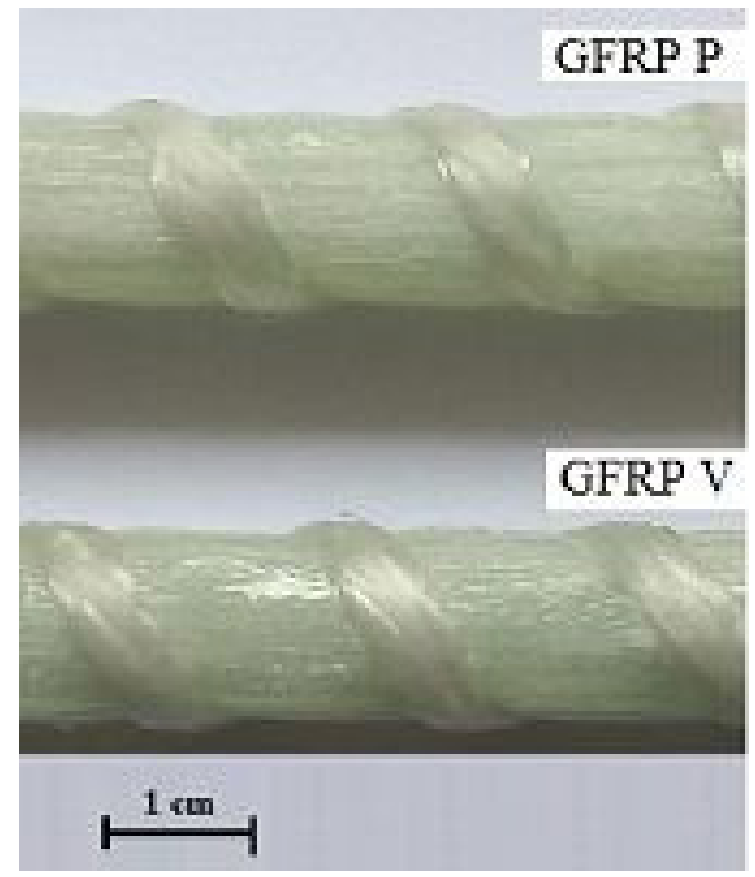

Figure 1. Tested GFRP rebars.

Table 1. Physical properties of GFRP rebars.

\begin{tabular}{lccrr}
\hline \multirow{2}{*}{ Property } & \multirow{2}{*}{ Unit } & Standardized Testing & \multicolumn{2}{c}{ Type of GFRP rebars } \\
\cline { 3 - 5 } & & Procedure & GFRP P & GFRP V \\
\hline Density & $\mathrm{g} / \mathrm{cm}^{3}$ & ASTM D792 & $2.1 \pm 0.1$ & $2.0 \pm 0.1$ \\
\hline Fiber content, by mass & $\%$ & ASTM D3171 & \\
\hline Cross-sectional area & $\mathrm{mm}^{2}$ & ASTM D7205 & $82.2 \pm 0.1$ & $12.8 \pm 0.1$ \\
\hline
\end{tabular}




\subsection{Scanning electron microscopy (SEM)}

The microstructure of the GFRP rebar was evaluated before and after aging, using a scanning electron microscope (VEGA 3 LMU TESCAN) containing secondary electron (SE) and backscattered electron detectors (BSE), voltage source for $20 \mathrm{kV}$, and tungsten filament. Samples $10 \mathrm{~mm}$ long were cut transversely with respect to the axis, and then polished and metalized with a thin layer of gold by a vacuum deposition process.

The micrographs were used to identify the changes in the fibers in the matrix and fiber-matrix interface, resulting from the exposure to the alkaline environment.

\subsection{Moisture absorption test}

The moisture uptake of the GFRP bars at saturation was determined according to ASTM D57024. Three specimens of each type of GFRP rebar were cut, dried, and weighed prior to immersion in the solutions at $23{ }^{\circ} \mathrm{C}$ and $60{ }^{\circ} \mathrm{C}$ for $1000 \mathrm{~h}$. The samples were removed from the solution after 4, 16, 64, 144, 256, 400, 576, 784, and $1000 \mathrm{~h}$, and were surface dried and weighed. The percentage moisture uptake, $M \%$, was measured through gravimetric means using the following Equation 1:

$$
M \%=\frac{W_{t}-W_{0}}{W_{0}} \times 100
$$

where $w_{t}$ is the weight of the wet specimen and $w_{o}$ is the weight of the dry specimen. The moisture on the surface of the bar specimens was carefully removed before weighing.

Normally, the fluid absorption of FRP follows Fick's Law in the first part of the exposure time; the quantity of absorbed fluid increases linearly over a certain period until it reaches saturation. The absorption nearly ceases as the FRP rebar becomes saturated. In some situations, the equilibrium moisture concentration is not reached, and the absorption of fluids continues to occur, but without following Fickian kinetics. This diffusion behavior of the FRP rebar, shown in Figure 2, normally occurs when there is degradation or cracking in the resin ${ }^{25,26}$.

From the evaluation of the initial linear stretch of the fluid absorption curve, shown in Figure 2, it is possible to obtain the moisture diffusion coefficient (D), in $\mathrm{mm}^{2} / \mathrm{min}$, using Equation $2^{27}$ :

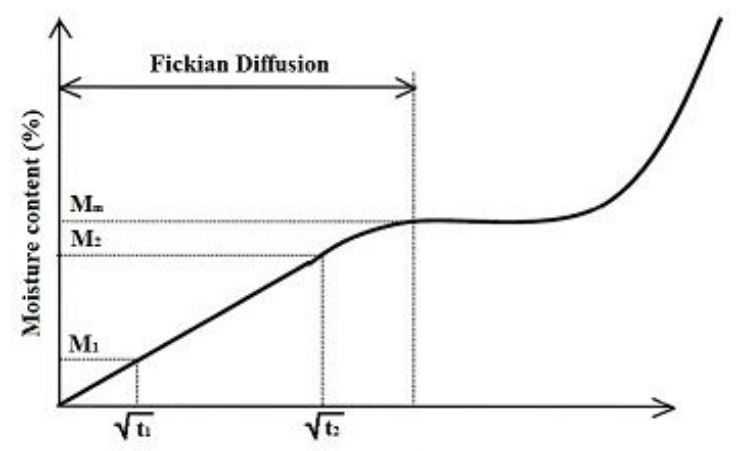

Square root of time (min)

Figure 2. Typical absorption behavior of FRP composites.
$D=\frac{\pi}{16}\left[\frac{h\left(M_{2}-M_{1}\right)}{M_{m}\left(\sqrt{t_{2}}-\sqrt{t_{1}}\right)}\right]^{2}$

where $M_{m}$ is the percentage of moisture at the end of linear behavior, $M_{1}$ is the percentage moisture after time $t_{1}, M_{2}$ is the percentage moisture after time $t_{2}$, and $h$ is the sample thickness (the diameter of the FRP rebar is considered for $h$ ).

\subsection{X-ray fluorescence spectrometry $(X R F)$}

Chemical analysis of the glass fibers was conducted before and after the aging process. Initially, the GFRP rebars were calcinated, according to the ASTM D317121. The samples were then prepared by griding the glass fiber using a jaw mill into a fine powder and sieving through a \# $75 \mu \mathrm{m}$ sieve. After milling, glass fibers were chemically characterized by x-ray fluorescence (XRF) using a Bruker model S2 Ranger spectrophotometer.

\subsection{Fourier-transform infrared spectroscopy (FTIR)}

FTIR was used to identify the changes in the chemistry of the polymeric matrix before and after aging. FTIR analyses were performed using a Shimadzu IRPrestige-21 spectrometer, with an attenuated total reflection (ATR) device. Three specimens (10 $\mathrm{mm}$ long) were prepared, and the IR spectra were obtained within wavenumber range of $4000-600 \mathrm{~cm}^{-1}$ at a resolution of $16 \mathrm{~cm}^{-1}$.

\subsection{Differential scanning calorimetry (DSC)}

Polymeric resin samples taken from the GFRP rebars were examined by DSC using a Shimadzu calorimeter. Specimens, in the range of $10 \mathrm{mg}$, were sealed in aluminum pans and prepared for analysis. DSC curves were obtained by heating the samples from 25 to $250{ }^{\circ} \mathrm{C}$ at a heating rate of $10^{\circ} \mathrm{C} / \mathrm{min}$, in a nitrogen atmosphere. The glass transition temperature $\left(\mathrm{T}_{\mathrm{g}}\right)$ was determined according to the ASTM E1356 standard ${ }^{28}$.

\subsection{Tensile test}

Tensile tests were performed according to the ASTM D $7205^{22}$ standard to determine the tensile resistance and elastic modulus of the GFRP rebars. The two ends of the rebar were anchored in a steel pipe, (150 mm long), with an outer diameter of $34 \mathrm{~mm}$, as shown in Figure 3. The pipe was then
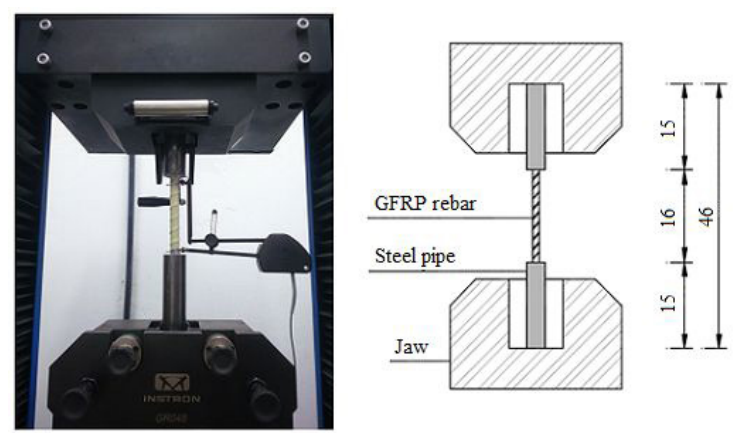

Figure 3. Tensile test setup (length in centimeters). 
installed at each end of the sample with epoxy resin, using a support frame to ensure perfect alignment of the pipes. The tensile test was performed on three replicates of each batch using an INSTRON 23-200 servo-electric universal testing machine. Displacement-controlled loading was performed at a rate of $2 \mathrm{~mm} / \mathrm{min}$. An extensometer (clip gauge) was attached to the middle of the bar to determine the strain. Data acquisition was used to capture load and strain readings.

\section{Results and Discussion}

\subsection{Chemical degradation of resin of GFRP rebar}

The SEM images of the cross-section of the GFRP rebars, shown in Figures 4-6, were used to characterize the modification of morphology after aging. In Figure 4, it is possible to identify, before aging, that there was no uniformity in the thickness of the resin layer around the glass fiber. For the vinylester GFRP rebar, a variation in the thickness of the resin covering in the range of $0-87 \mu \mathrm{m}$ was observed, whereas, for the polyester GFRP rebar, this variation was in the range of 9-79 $\mu \mathrm{m}$. The reduction in thickness represents a loss of protection of the fiber glass, and it can be associated with the production of the GFRP rebar or resin shrinkage during the curing cycle due polymerization reaction ${ }^{29}$. In addition to the variation in the resin layer around the glass fibers, it was possible to observe the presence of small defects (Figures $4 \mathrm{a}, \mathrm{b}$ ) in the GFRP rebars with a polyester matrix. In fact, the determination of the porosity of the bar, according to the ASTM D3171 standard ${ }^{21}$, indicated a void content of $4.3 \%$ for GFRP with a polyester matrix. Disconnected voids were also observed by Gooranorimi et al. ${ }^{30}$ over the entire cross-section of GFRP rebars. The SEM image of the unaged GFRP rebar with the vinylester matrix does not indicate any defects (Figures 4c, d).

The effect of hydrothermal aging on the microstructure of the GFRP rebars is shown in Figures 5 and 6 for exposition at $23{ }^{\circ} \mathrm{C}$ and $60{ }^{\circ} \mathrm{C}$, respectively. For aging at $23{ }^{\circ} \mathrm{C}$, it verified the presence of more voids and microcracks in the polyester resin while the vinylester matrix does not show degradation. The aging of the bars in solution at $60^{\circ} \mathrm{C}$, on the other hand, resulted in greater deterioration in both resins,
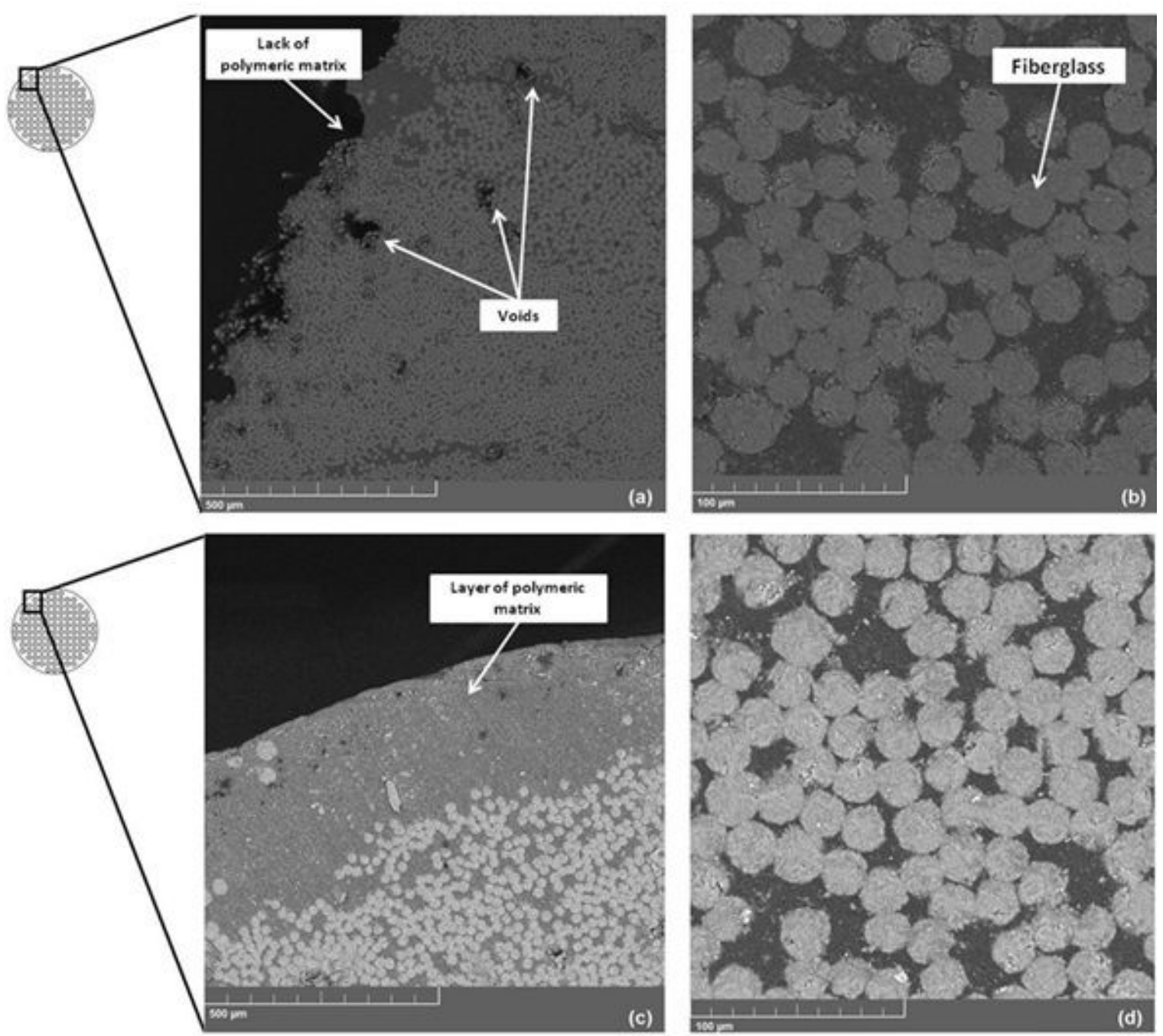

Figure 4. SEM micrographs of unaged GFRP rebars: (a, b) Polyester matrix; (c, d) Vinylester matrix. 

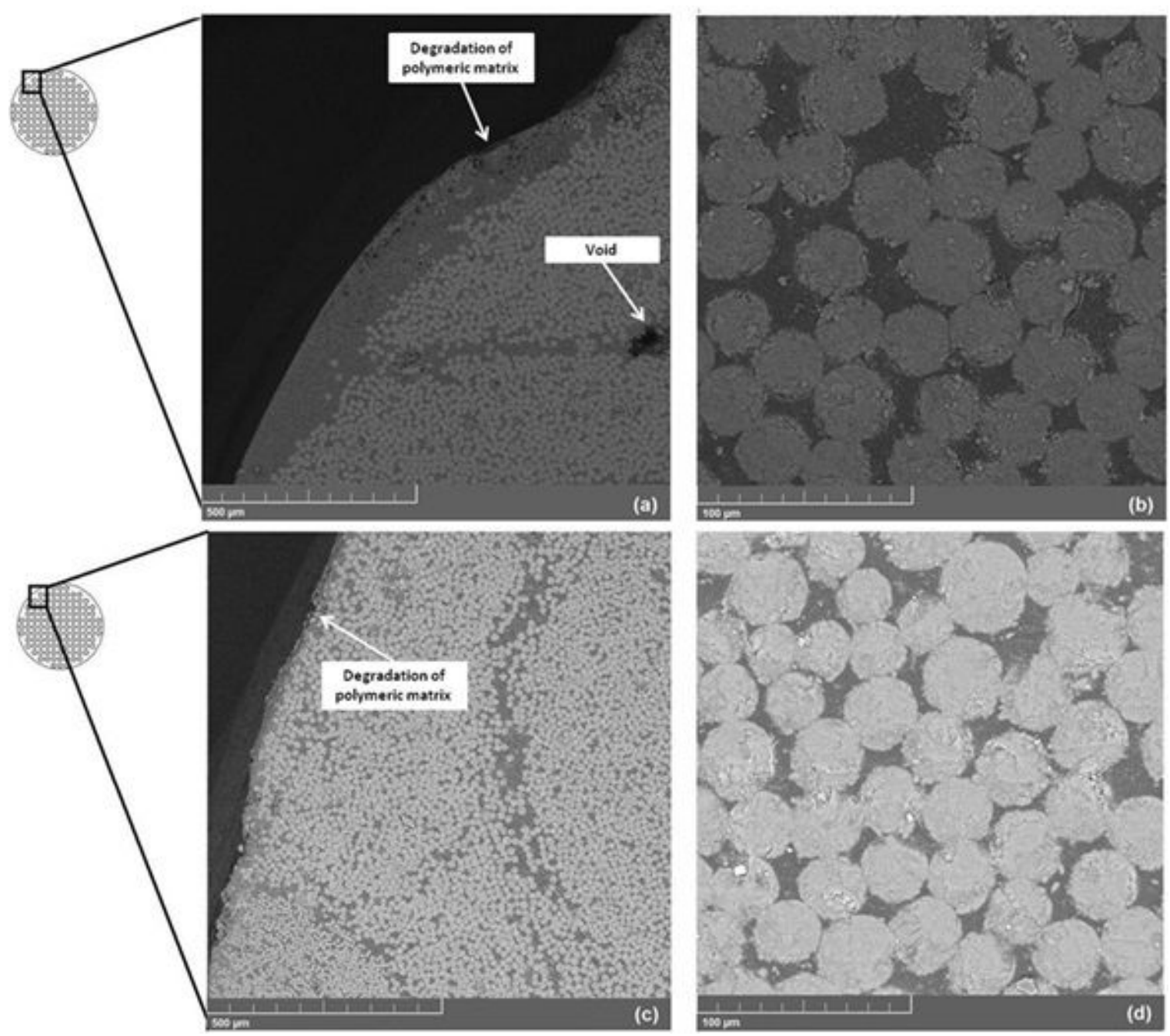

Figure 5. SEM micrographs of aged GFRP rebars at $23{ }^{\circ} \mathrm{C}$ : (a, b) Polyester matrix; (c, d) Vinylester matrix.

with the formation of pores in the surface layer and the resin located inside the rebar. Consequently, one detachment is verified between fiber and matrix.

The deterioration of the resins is caused by the alkaline attack: the free hydroxyls $\left(\mathrm{OH}^{-}\right)$react chemically with the ester group (the weakest bond in the vinylester and polyester matrices), causing hydrolysis in the polymeric matrix with the formation of alcohol and salt of carboxylic acid, according to Equation $3^{11,31}$.

$$
\mathrm{R}-\mathrm{C}_{-\mathrm{O}-\mathrm{R}}^{\mathrm{O}}+\mathrm{OH}^{-} \longrightarrow \mathrm{R}-\mathrm{C}_{-}^{\prime \prime}{ }^{\mathrm{O}-\mathrm{H}}+\mathrm{OH}-\mathrm{R}
$$

The intensity at which reaction (3) occurs is a function of the temperature, time, alkalinity, and type of polymeric matrix. The FTIR spectra of GFRP rebars, presented in Figure 7, were used to identify any chemical modifications after aging. Two regions of the infrared spectrum were studied: the $\mathrm{CH}$ band $\left(2800-3030 \mathrm{~cm}^{-1}\right)$, associated with the carbon-hydrogen group, and $\mathrm{OH}$ band (3050-3600 $\left.\mathrm{cm}^{-1}\right)$, which corresponds to the stretching mode of the hydroxyl groups. Four spectra of each GFRP rebar were obtained for the core and surface and the $\mathrm{OH} / \mathrm{CH}$ ratio was calculated according to Benmokrane et al. ${ }^{16}$, as shown in Figure 8.

Hydrolysis leads to a variation in the $\mathrm{OH}$ infrared band, but it does not affect the $\mathrm{CH}$ content. Therefore, the $\mathrm{OH} / \mathrm{CH}$ ratio can be used to indicate the relative amount of hydroxyl in the sample. Table 2 presents the results for the $\mathrm{OH} / \mathrm{CH}$ ratio. The rebars with polyester resin showed a reduction of up to $18 \%$ in the ratio $\mathrm{OH} / \mathrm{CH}$ ratio, which indicates the occurrence of chemical degradation of the polymer when exposed to the alkaline solution. For vinylester resin, the maximum variation in the $\mathrm{OH} / \mathrm{CH}$ ratio was $5 \%$, confirming the better chemical resistance of this resin already observed by other authors ${ }^{32}$, which can be explained by the existence of fewer ester groups than the isophthalic polyester resin, and the existence of terminal methyl groups, which protect the ester groups s $^{31,33,34}$.

The effect of hydrothermal aging on the glass transition temperatures $\left(\mathrm{T}_{\mathrm{g}}\right)$ of the resins is shown in Table 3 and indicates a reduction in $\mathrm{T}_{\mathrm{g}}$ with an increment in temperature of the solution. 

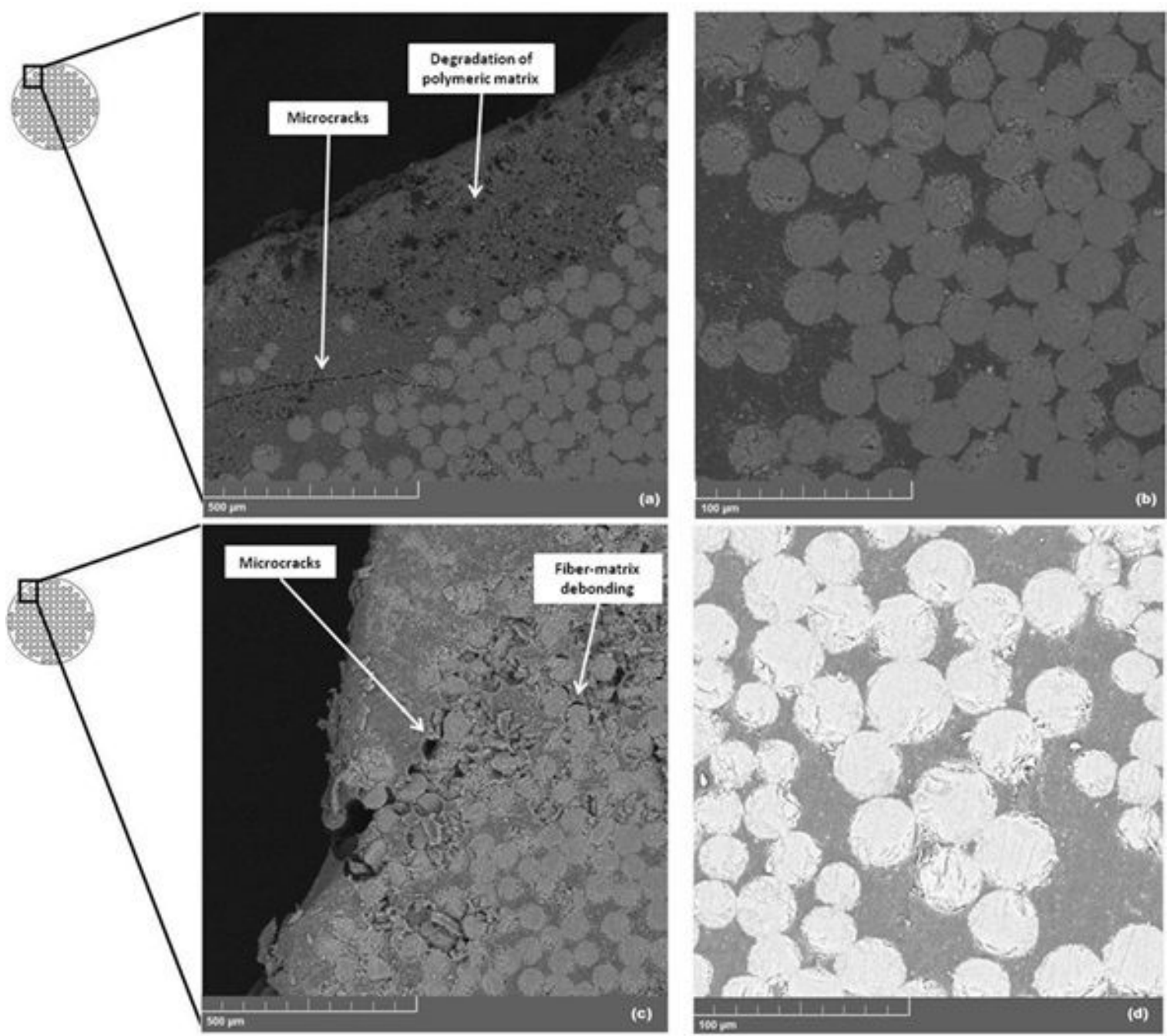

Figure 6. SEM micrographs of aged GFRP rebars at $60{ }^{\circ} \mathrm{C}$ : (a, b) Polyester matrix; (c, d) Vinylester matrix.

Table 2. $(\mathrm{OH} / \mathrm{CH})$ Ratio of the FTIR peaks.

\begin{tabular}{cccc}
\hline \multirow{2}{*}{ Matrix } & \multicolumn{3}{c}{ Surface } \\
\cline { 2 - 4 } & Reference (unaged) & $2{ }^{\circ} \mathrm{C}$ & $60{ }^{\circ} \mathrm{C}$ \\
\hline Polyester & 1.05 & 0.86 & 0.91 \\
\hline Vinylester & 1.00 & 1.04 & 1.05 \\
\hline
\end{tabular}

Table 3. Glass transition temperature $\left(\mathrm{T}_{\mathrm{g}}\right)$ of GFRP rebars before and after alkaline attack at different temperatures.

\begin{tabular}{cccc}
\hline \multirow{2}{*}{ Matrix } & \multicolumn{3}{c}{ Status } \\
\cline { 2 - 4 } & Control & Solution $23{ }^{\circ} \mathrm{C}$ & Solution $60{ }^{\circ} \mathrm{C}$ \\
\hline Polyester & 108.2 & 100.1 & 96.3 \\
\hline Vinylester & 103.7 & 97.2 & 95.4 \\
\hline
\end{tabular}

The polyester resin showed a reduction of $7.5 \%$ and $11.0 \%$ of $\mathrm{T}_{\mathrm{g}}$ for a solution temperature of $23^{\circ} \mathrm{C}$ and $60{ }^{\circ} \mathrm{C}$, respectively. The vinylester resin, in turn, showed reductions of $6.3 \%$ and $8.0 \%$, respectively. This reduction in $\mathrm{T}_{\mathrm{g}}$ due to alkaline attack and increase in temperature, also observed by other researchers ${ }^{16,35}$, has been used as an indicator of deterioration of polymeric resin exposed to aggressive environments over time ${ }^{36}$ since it is associated with irreversible chemical changes.

\subsection{Moisture diffusion kinetics of GRFP rebar}

Figure 9 shows the moisture diffusion curves for polyester and vinylester GFRP rebars in alkaline solutions at $23^{\circ} \mathrm{C}$ and $60^{\circ} \mathrm{C}$. An initial period of linear diffusion was observed until a time of $4 \mathrm{~h}^{1 / 2}$, independent of the type of resin or temperature of the solution, and the curves show the shape of a typical Fickian diffusion curve, with the saturated moisture concentration $\mathrm{M}_{\mathrm{m}}$ representing the maximum 

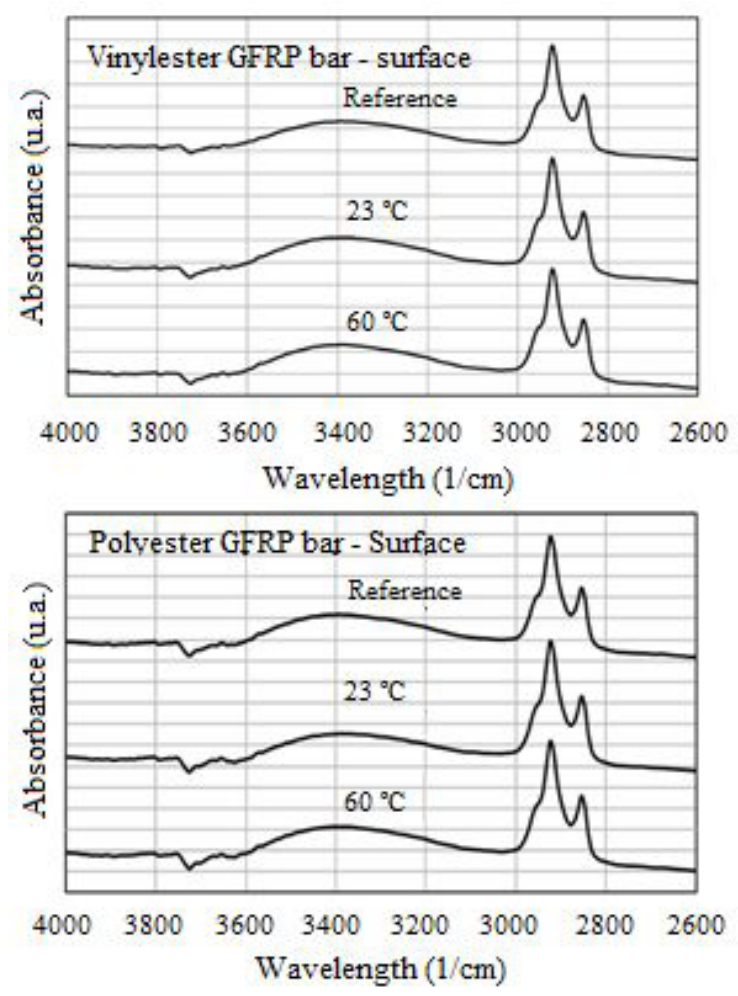

Figure 7. FTIR spectra conditioned GFRP rebars.

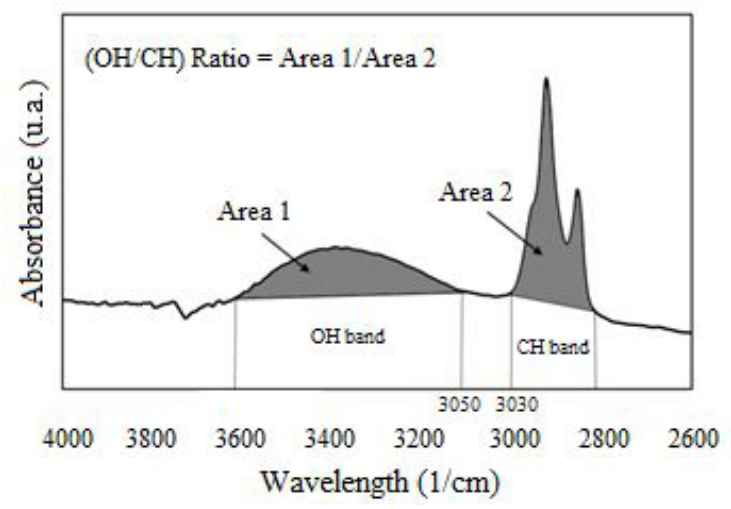

Figure 8. Determination of $(\mathrm{OH} / \mathrm{CH})$ ratio.

moisture content absorbed by the specimen. After this time, the diffusion curves exhibited distinct behaviors.

The GFRP rebar with vinylester resin, immersed in the solution at $23{ }^{\circ} \mathrm{C}$, exhibited a gradual reduction in weight with time. This behavior can be attributed to the hydrolysis of ester groups and the subsequent leaching of low molecular mass and water-soluble components of the resin into the alkaline solution ${ }^{37}$. This leaching process, also verified by Arias et al. ${ }^{38}$, can be confirmed by the voids observed in the resin (see Figure 4) after the aging process. This phenomenon was not observed in the GFRP rebar with vinylester resin.

However, when immersed in solution at $60{ }^{\circ} \mathrm{C}$, the materials do not fully conform to the classical predictions, and they continue to gain weight after an apparent pause, as

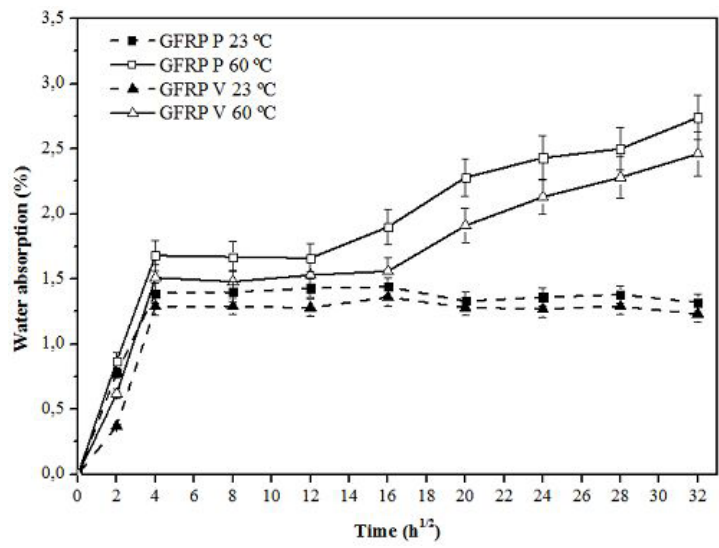

Figure 9. Absorption behavior of GFRP rebars immersed in alkaline solution at different temperatures.

already reported by Upadhyay and Misra ${ }^{39}$. The absorption curves then exhibit a non-Fickian two-stage sorption behavior, wherein the initial uptake is rapid and a linear function of the square root of time. Micelli et al. ${ }^{25}$ observed a similar behavior for FRP rebars with epoxy or vinylester resins reinforced with carbon fiber, with an increase in fluid absorption after immersion at $60^{\circ} \mathrm{C}$. According to the authors, this highlights the important role of temperature in the absorption kinetics of polymeric resins.

Won et al. ${ }^{26}$ considered that this increase in water absorption due to the penetration of moisture in the cracks developed in the degraded resin. The micrographs obtained in this work (Figure 6) indicate that the exposure of the resins to a temperature of $60{ }^{\circ} \mathrm{C}$ causes damage and cracks that allow the migration of fluids into the interior of the rebar, increasing its capacity for absorbing moisture. Thus, after a period of initial stabilization of the moisture content, the moisture absorption of the FRP rebars increases again for both resins, but at different periods. The polyester and vinylester rebars exposed to the alkaline solution at $60{ }^{\circ} \mathrm{C}$ showed a different rate of linear increase in moisture absorption after $144 \mathrm{~h}$ and $256 \mathrm{~h}$. The non-Fickian moisture absorption behavior may also be due to the gradual capillary transport of water molecules to the fiber-matrix interfaces during the conditioning period ${ }^{32,40}$. This indicates that the fluid penetrates inside the composite, causing potential damage to the fibers when the fluid contains ions that are chemically aggressive for that type of fiber; Micelli et al..$^{25}$ also observed this phenomenon.

The experimentally obtained values of the saturation concentration of moisture $\left(\mathrm{M}_{\mathrm{m}}\right)$ and the solution diffusion coefficients (D), calculated using Equation 2, are presented in Table 4.

It is confirmed that the values of saturation concentration of moisture $\left(M_{m}\right)$ and the diffusion coefficients $(D)$ for the rebars with vinylester matrix are lower than those for the rebars with polyester resin, regardless of the temperature of the aging solution. Kamal et al. ${ }^{41}$ evaluated composites with the same types of resins and observed that composites with vinylester resin absorb less water than those with isophthalic polyester matrices. 
The increase in temperature of the alkaline solution increased the saturation concentration of moisture $\left(M_{m}\right)$ by up to $5.9 \%$ and an increase in the diffusion coefficients $(D)$ of up to $13.3 \%$; this is because a higher temperature results in greater kinetic movement of water molecules and polymer, facilitating the penetration of moisture in the resin, as already verified by other authors ${ }^{42,43}$. Furthermore, the low moisture uptake and diffusion coefficient values in vinylester resin were associated with fewer hydrophilic properties because they contain fewer polar ester fraction ${ }^{44}$.

The increase in water absorption by the GFRP rebars was also facilitated by the progression of the hydrolysis reaction (see FTIR results).

The infiltration of water into the polymeric matrix causes separation of molecular chains and induces internal tension, a phenomenon known as plasticization ${ }^{35,45}$, which can generate microcracks inside the GFRP $\operatorname{rebar}^{26}$. The comparison of the $T_{g}$ values, listed in Table 3 , and the water absorption results, listed in Table 4, corroborate these results. The polyester resin, which showed the maximum reduction in $T_{g}$, showed the highest absorption of water and increased diffusion coefficient with increasing temperature.

\subsection{Chemical degradation of glass fibers of GFRP rebar}

According to the chemical composition of the glass fiber, shown in Table 5, it can be classified as type E glass fiber. This fiber has low chemical resistance ${ }^{46}$ and high sensitivity to the alkaline environment ${ }^{47}$. Therefore, its use is not recommended for reinforcing cementitious materials, which have high alkalinity. In GFRP rebars, the glass fibers are protected from the external environment by the resin layer, but with its degradation there is the possibility of the alkaline solution meeting the fibers, causing their deterioration. In fact, Table 5 shows that there was a change in the chemical composition of glass fiber after hydrothemal aging. Noteworthy is the change in sodium content that varied $11 \%$ with increasing temperature. Alkaline ions, such as sodium $\left(\mathrm{Na}^{+}\right)$, react chemically on the surface of the glass fiber, causing significant changes in the $\mathrm{Na}_{2} \mathrm{O}$ content. These reactions are potentiated by the breaking of the $\mathrm{Si}-\mathrm{O}-\mathrm{Si}$ structure of the glass fibers ${ }^{7,13}$, caused by hydroxyl ions, according to the reactions presented in Equations 4-6. In addition, the kinetics of these equations were altered with the increase in temperature from $23^{\circ} \mathrm{C}$ to $60^{\circ} \mathrm{C}$, resulting in higher $\mathrm{Na}_{2} \mathrm{O}$ content.

$$
\begin{aligned}
& \mathrm{Si}-\mathrm{O}-\mathrm{Na}+\mathrm{H}_{2} \mathrm{O} \rightarrow \mathrm{Si}-\mathrm{OH}+\mathrm{Na}^{+}+\mathrm{OH}^{-} \\
& \mathrm{Si}-\mathrm{O}-\mathrm{Si}+\mathrm{OH}^{-} \rightarrow \mathrm{Si}-\mathrm{OH}+\mathrm{Si}-\mathrm{O}^{-} \\
& \mathrm{Si}-\mathrm{O}^{-}+\mathrm{H}_{2} \mathrm{O} \rightarrow \mathrm{Si}-\mathrm{OH}+\mathrm{OH}^{-}
\end{aligned}
$$

\subsection{Mechanical degradations of GFRP rebar}

Table 6 presents the experimental results obtained from tensile testing for the ultimate strength and elastic modulus of the unaged and aged GFRP rebars tested after accelerated aging at $23{ }^{\circ} \mathrm{C}$ and $60{ }^{\circ} \mathrm{C}$.

The tensile strength of the unaged GFRP rebars is in the range of $862-881 \mathrm{MPa}$. These values are higher than those found by Robert and Bermokrane ${ }^{48}$ for GFRP rebars with vinylester resin, and well as the typical values of

Table 4. Saturation concentration of moisture $\left(\mathrm{M}_{\mathrm{m}}\right)$ and diffusion coefficients (D) of GFRP rebars.

\begin{tabular}{|c|c|c|c|c|c|c|c|c|c|c|c|}
\hline \multirow{2}{*}{ Sample } & \multirow{2}{*}{$\begin{array}{c}\text { Temp. } \\
\left({ }^{\circ} \mathrm{C}\right)\end{array}$} & \multicolumn{10}{|c|}{ Constituents (\%) } \\
\hline & & $\mathrm{SiO}_{2}$ & $\mathrm{Al}_{2} \mathrm{O}_{3}$ & $\mathrm{CaO}$ & $\mathrm{MgO}$ & $\mathrm{TiO}_{2}$ & $\mathrm{Na}_{2} \mathrm{O}$ & $\mathrm{Fe}_{2} \mathrm{O}_{3}$ & $\mathrm{~K}_{2} \mathrm{O}$ & Other & LOI* \\
\hline \multirow{3}{*}{ GFRP P } & Control & 53.76 & 12.92 & 28.17 & 4.17 & 0.10 & - & 0.39 & 0.32 & 0.17 & 0.11 \\
\hline & 23.0 & 52.61 & 12.73 & 28.47 & 4.27 & 0.10 & 0.95 & 0.40 & 0.32 & 0.15 & 0.12 \\
\hline & 60.0 & 52.19 & 13.09 & 28.35 & 4.23 & 0.11 & 1.10 & 0.44 & 0.33 & 0.16 & 0.12 \\
\hline \multirow{3}{*}{ GFRP V } & Control & 52.93 & 12.76 & 28.95 & 4.25 & 0.12 & - & 0.45 & 0.36 & 0.20 & 0.14 \\
\hline & 23.0 & 52.86 & 12.89 & 28.16 & 4.33 & 0.10 & 1.05 & 0.39 & 0.35 & 0.16 & 0.12 \\
\hline & 60.0 & 52.09 & 12.68 & 28.85 & 4.23 & 0.11 & 1.13 & 0.39 & 0.33 & 0.18 & 0.10 \\
\hline
\end{tabular}

\begin{tabular}{llllll}
\hline \multirow{2}{*}{ Parameter } & \multicolumn{3}{c}{ GFRP P } & \multicolumn{2}{c}{ GFRP V } \\
\cline { 2 - 3 } \cline { 5 - 6 } & $\mathrm{T}=23{ }^{\circ} \mathrm{C}$ & $\mathrm{T}=60{ }^{\circ} \mathrm{C}$ & $\mathrm{T}=23{ }^{\circ} \mathrm{C}$ & $\mathrm{T}=60{ }^{\circ} \mathrm{C}$ \\
\hline $\mathrm{M}_{\mathrm{m}}(\%)$ & $1.5 \pm 0.1$ & $1.7 \pm 0.3$ & & $1.3 \pm 0.2$ & $1.4 \pm 0.3$ \\
\hline $\mathrm{D}\left(10^{-4} \mathrm{~mm}^{2} / \mathrm{min}\right)$ & $5.9 \pm 0.4$ & $5.9 \pm 0.2$ & & $1.8 \pm 0.1$ & $4.4 \pm 0.2$ \\
\hline
\end{tabular}

Table 5. Glass fiber composition (\% by weight) of samples extracted from GFRP rebars with polyester (P) and vinylester (V) matrices.

\begin{tabular}{|c|c|c|c|c|}
\hline Sample & Matrix & Temperature $\left({ }^{\circ} \mathrm{C}\right)$ & Average tensile strength $(\mathrm{MPa})$ & Average elastic modulus (GPa) \\
\hline \multirow{3}{*}{ GFRP P } & \multirow{3}{*}{ Polyester } & Control & $881.7 \pm 19.8$ & $51.3 \pm 0.5$ \\
\hline & & 23.0 & $831.5 \pm 19.1$ & $50.8 \pm 0.6$ \\
\hline & & 60.0 & $825.0 \pm 18.5$ & $50.7 \pm 1.0$ \\
\hline \multirow{3}{*}{ GFRP V } & \multirow{3}{*}{ Vinylester } & Control & $862.8 \pm 15.4$ & $51.8 \pm 0.5$ \\
\hline & & 23.0 & $829.9 \pm 23.7$ & $51.1 \pm 0.4$ \\
\hline & & 60.0 & $815.5 \pm 34.8$ & $50.6 \pm 1.4$ \\
\hline
\end{tabular}

*LOI: Loss on ignition

Table 6. Experimental results of tensile tests on GFRP rebars subjected to hydrothermal aging at $23{ }^{\circ} \mathrm{C}$ and $60{ }^{\circ} \mathrm{C}$. 
tensile strength indicated by the standard ACI $440.1 \mathrm{R}^{49}$ for GFRP rebars.

As expected, there was a reduction in the tensile strength and elasticity modulus of the aged GFRP rebars. These results are compared in Figure 10. It appears that the type of resin used in the production of the rebars also affects the loss of strength of the rebars. There was a reduction in tensile strength of $5.7 \%$ and $3.8 \%$ for the GFRP rebars with polyester matrix and vinylester, respectively, after they were exposed to the alkaline solution at a temperature of $23{ }^{\circ} \mathrm{C}$. The exposure of the GFRP rebars to the solution at a temperature of $60^{\circ} \mathrm{C}$ generated a more intense alkaline attack, and the strength reductions were $6.4 \%$ and $5.5 \%$ for the GFRP rebars with polyester matrix and vinylester, respectively. The trend of decrease in the mechanical properties of GFRP rebars after the alkaline attack corroborates the results obtained by several authors ${ }^{3,6,14}$ who found a reduction in the tensile strength of GFRP rebars subjected to alkaline attack at temperatures of 20 ${ }^{\circ} \mathrm{C}$ and $60{ }^{\circ} \mathrm{C}$. The reduction was in the range of $5.0-16.0 \%$. Despite the reduction in tensile strength, the variation in the values of the modulus of elasticity of the GFRP rebars was not significant, with a maximum reduction of $2.3 \%$ for the rebars with vinylester matrix, after they were exposed to an alkaline environment at $60^{\circ} \mathrm{C}$.

The reduction in tensile strength observed in the rebars subjected to hydrothermal aging is compatible with the damage observed in the resin microstructure, which also increased the water absorption of the rebar. The rebars with polyester matrix, which showed greater microstructural damage, also showed greater loss of tensile strength. The better performance of bars with vinylester matrix, after immersion in alkaline solution, is associated with the greater chemical stability of this resin, which presented less alkaline hydrolysis and, consequently, less damage (voids) and less water absorption, as shown previously.

Damage to glass fiber also contributed to the reduction in the mechanical performance of the GFRP rebars. The fiber is the main element responsible for the mechanical strength of the GFRP rebar because it has a greater volume than the matrix, and for realizing a tensile strength superior to that of the polymeric resin ${ }^{19,46}$. Thus, the analysis of the reduction in tensile strength observed in the GFRP rebars, when subjected to an alkaline environment, indicates that the glass fibers are damaged by the solution.

The damage identified in the glass fiber, with the modification of its chemical composition, also contributed to the reduction in mechanical performance. As fiber is the main component of the GFRP rebar due to the volume occupied and the greater tensile strength, even small damages can result in important changes in mechanical behavior and need to be quantified.

\subsection{Theoretical assessment of mechanical damage}

The tensile strength depends on the integrity of the matrix, amount and integrity of fibers, and fiber-matrix interaction ${ }^{50}$. However, in a simplified way, the tensile strength of the composite reinforced with aligned fibers can be determined by the contribution of each phase, matrix, and fiber, and can be expressed by the mixture rule, according to Equation 7.

$\sigma_{c}=\sigma_{f} V_{f}+\sigma_{m} V_{m}$

where $\sigma_{c}, \sigma_{f}$, and $\sigma_{m}$ represent the tensile strengths of the composite, fiber, and matrix, respectively. $V_{f}$ and $V_{m}$ indicate the fiber and matrix contents, respectively, in the GFRP rebar.

Thus, the total loss of tensile strength due to alkaline attack is proportional to the extent of mechanical damage in each phase that had contact with aggressive agents. The resin degradation mechanism was intensified by increasing the temperature to $60{ }^{\circ} \mathrm{C}$, which provided the intermolecular penetration of hydroxyl ions into the resin and later into the glass fibers, as shown in the simplified model in Figure 11.

The residual tensile strength of the rebar $\bar{\sigma}_{c}$ can then be defined by Equation 8 , with $\bar{\sigma}_{f}$ and $\bar{\sigma}_{m}$ representing the residual strengths of the fiber and the matrix after aging, respectively.

$\bar{\sigma}_{c}=\bar{\sigma}_{f} V_{f}+\bar{\sigma}_{m} V_{m}$

Considering isotropic damage, the residual strengths of the matrix and fiber can be determined by Equations 9 and 10 , respectively, where $D_{f}$ and $D_{m}$ represent the damage to the fiber and the matrix, respectively, due to the alkaline attack.
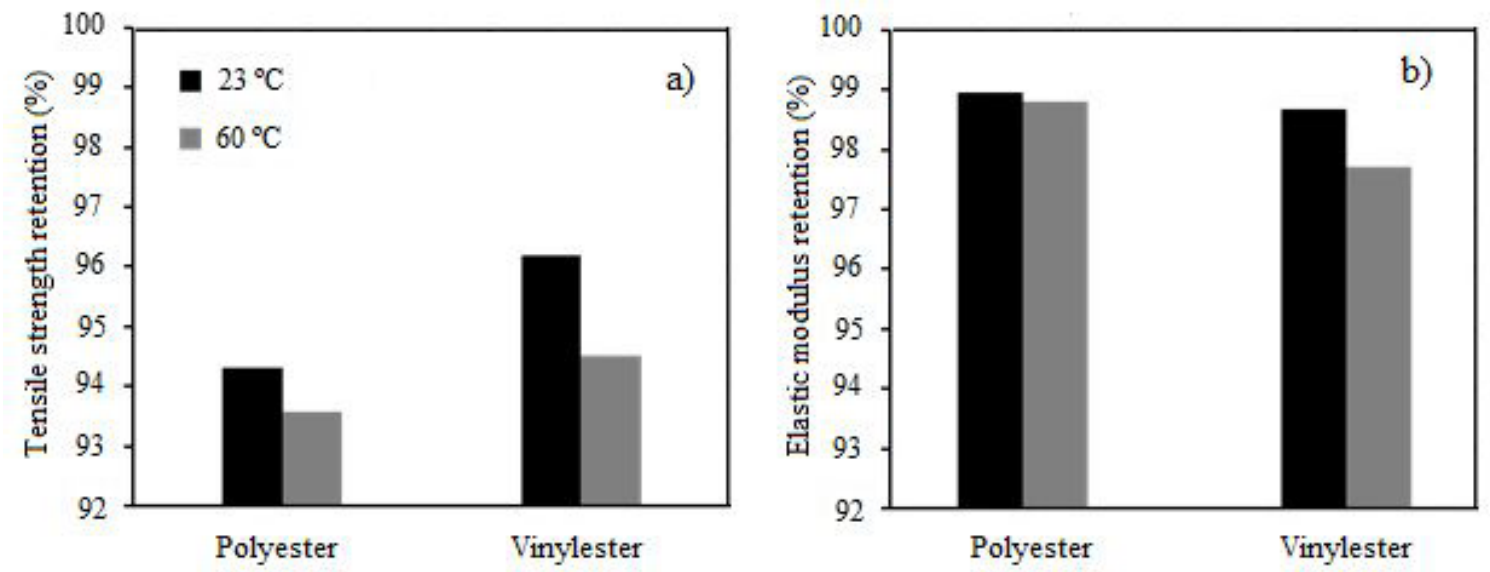

Figure 10. Comparison of tensile strength (a) and elastic modulus (b) reduction in GFRP rebars exposed to alkaline environment. 

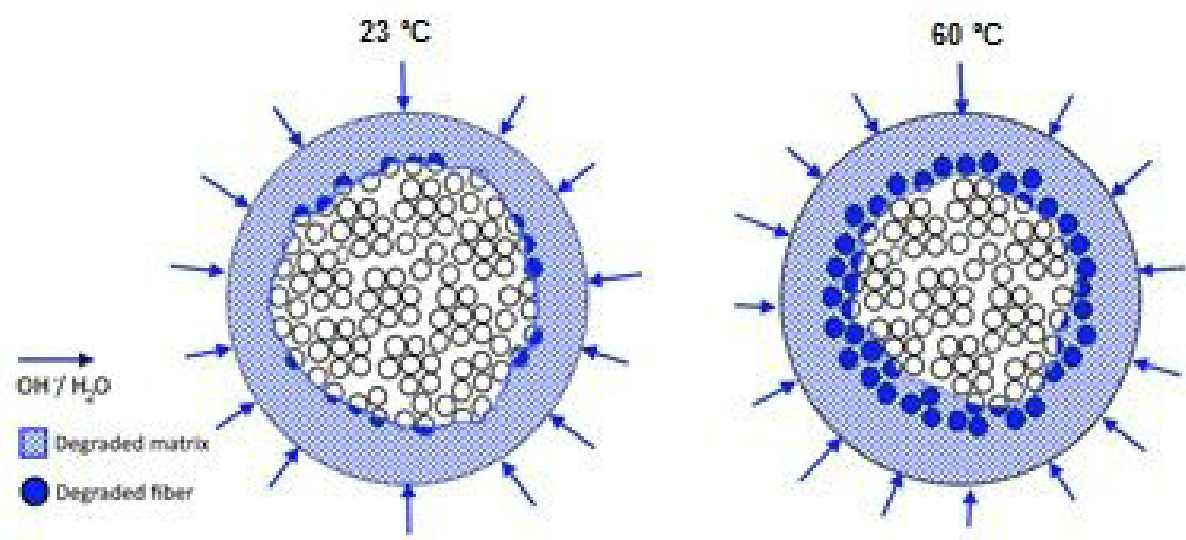

Figure 11. Degradation model of GFRP rebars in an alkaline environment.

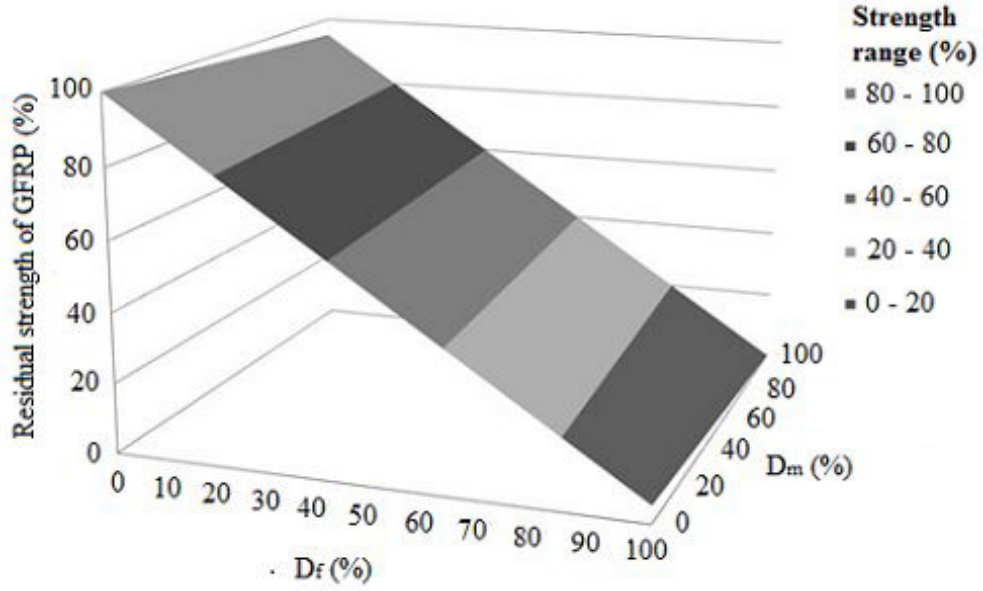

Figure 12. Residual strength of composite as a function of damage to the matrix and fiber for GFRP rebars with $60 \%$ glass fiber.

$\bar{\sigma}_{f}=\sigma_{f}\left(1-D_{f}\right)$

$\bar{\sigma}_{m}=\sigma_{m}\left(1-D_{m}\right)$

Thus, Equation 8 can be modified to obtain Equation 11.

$\bar{\sigma}_{c}=\sigma_{f}\left(1-D_{f}\right) V_{f}+\sigma_{m}\left(1-D_{m}\right) V_{m}$

Figure 12 shows the parametric study of Equation 11, for the GFRP rebars with a fiber volume of approximately $60 \%$, with values of $D_{f}$ (damage to the fiber) and $D_{m}$ (damage to the matrix) ranging from 0 to 1 . In the numerical simulation, a tensile strength of $1420 \mathrm{MPa}$ was adopted for the glass fiber, $60 \mathrm{MPa}$ and $98 \mathrm{MPa}$ for vinylester, and polyester resins, respectively ${ }^{18}$.

The tensile strength of the GFRP rebar is much more sensitive to the damage to the glass fiber than to the matrix. It is possible to estimate that, for a $100 \%$ damage in the matrix, the reduction in strength of the GFRP rebar with polyester is only $4.5 \%$ and the reduction in the GFRP rebar with vinylester is $2.8 \%$. These strength reduction values are lower than the values observed experimentally, as seen in Figure 10, which indicates that, in addition to the damage to the matrix, the accelerated aging resulted in mechanical damage to the glass fibers. This result corroborates the experimental observation of the modification of the glass fibers by the alkaline attack, which was already confirmed by the modification of the chemical composition of the fiber (Table 5).

The holes shown in Figure 13, obtained with Equation 11, allow the estimation of the damage in each component of the GFRP rebars due to the alkaline attack. Comparing the values of reduction of tensile strength, obtained for the alkaline attack at $23{ }^{\circ} \mathrm{C}$ and $60{ }^{\circ} \mathrm{C}$, it is possible to evaluate that the glass fibers suffered mechanical damage that varied from 1 to $4 \%$ for GFRP rebars with vinylester matrix and 1 to $6 \%$ for GFRP rebars with polyester matrix. The intersections between the dashed lines (which represent the $\%$ damage in the fiber) and the horizontal, black, and red solid lines (which represent the retention of resistance of the GFRP rebars) indicate the possible combinations of matrix damage and fiber damage due to alkaline attack. For example, for a GFRP rebar with a polyester matrix subjected to $23{ }^{\circ} \mathrm{C}$, the loss of tensile strength may result from the occurrence of $2 \%$ fiber damage and $85 \%$ matrix damage. 



Figure 13. Effect of matrix damage $\left(D_{m}\right)$ and fiber damage $\left(D_{f}\right)$ on the residual strength of GFRP rebars (dashed lines represent experimental results).

\section{Conclusion}

In this study, GFRP rebars manufactured with two types of matrices, vinylester and polyester, were subjected to hydrothermal aging in an alkaline solution for $1000 \mathrm{~h}$ at $23{ }^{\circ} \mathrm{C}$ and $60{ }^{\circ} \mathrm{C}$. SEM, absorption test, XRF, FTIR, DSC, and tensile tests were conducted to characterize the aging effect on the GFRP reinforcing rebar. Based on the results of this study, the following conclusions were drawn.

- The GFRP rebars with the polyester matrix showed greater water absorption than the bars with the vinylester matrix. Consequently, there was a greater extent of damage in the first type of rebar owing to hydrothermal aging, with the formation of microcracks and a reduction in the glass transition temperature.

- The fiber-matrix interface was damaged by aging, with the appearance of cracks and fiber debonding.

- The damage caused to the resin, which protects the glass fibers, caused alteration of their chemical structure; this was confirmed by the presence of $\mathrm{Na}^{+}$in the chemical composition and changes in the FTIR spectrum.

- The tensile strength of the GFRP rebars decreased with the alkaline attack and was significantly affected by the increase in temperature. The rebars with polyester resin showed a greater loss of tensile strength after hydrothermal aging.

- The evaluation of tensile strength using damage mechanics demonstrated that the reduction in tensile strength observed in the GFRP rebars from the experimental results, is possible only with the reduction in the tensile strength of the glass fibers embedded in the matrix. This confirms that an alkaline attack inhibits the protective function of the polymeric layer.

\section{Acknowledgements}

The authors would like to acknowledge the Materials Characterization Laboratory (Federal Institute of Bahia), the Stratus Company and the Sika Company.

\section{References}

1. Cruz CL, Lima TG, Sampaio NAS, Silva JWJ. Statistical study of corrosion types in constructions in south region of Rio de Janeiro - Brasil. Mater Sci Eng. 2016;7:23-32.

2. D'Antino T, Pisani MA, Poggi C. Effect of the environment on the performance of GFRP reinforcing bars. Compos, Part B Eng. 2018;141:123-36. http://dx.doi.org/10.1016/j. compositesb.2017.12.037.

3. Jia D, Guo Q, Mao J, Lv J, Yang Z. Durability of glass fibre-reinforced polymer (GFRP) bars embedded in concrete under various environments. I: experiments and analysis. Compos Struct. 2020;234:1-12. http://dx.doi.org/10.1016/j. compstruct.2019.111687.

4. Inman M, Thorhallsson ER, Azrague K. A mechanical and environmental assessment and comparison of basalt fibre reinforced polymer (BFRP) bar and steel bar in concrete beams. Energy Procedia. 2017;111:31-40. http://dx.doi.org/10.1016/j. egypro.2017.03.005.

5. Thomason JL. Glass fibre sizing: a review. Compos, Part A Appl Sci Manuf. 2019;127:1-24. http://dx.doi.org/10.1016/j. compositesa.2019.105619.

6. Fergani H, Benedetti MD, Oller CM, Lynsdale M, Guadagnini M. Durability and degradation mechanisms of GFRP reinforced subjected to severe environments and sustained stress. Constr Build Mater. 2018;170:637-48. http://dx.doi.org/10.1016/j. conbuildmat.2018.03.092.

7. Helebrant A, Hradecka H, Holubova B, Brazda L, Netusilova M, Zlamalova-Cilovam Z. Kinetics of processes modeling corrosion of glass fibers mixed into concrete. Ceram Silik. 2017;61:163-71. http://dx.doi.org/10.13168/cs.2017.0012.

8. Li C, Xian G, Li H. Water absorption and distribution in a pultruded unidirectional carbon/glass hybrid rod under hydraulic pressure and elevated temperatures. Polymers. 2018;627:1-17. http://dx.doi.org/10.3390/polym10060627.

9. Yin X, Liu Y, Miao Y, Xian G. Water absorption, hydrothermal expansion, and thermomechanical properties of a vinylester resin for fiber-reinforced polymer composites subjected to water or alkaline solution immersion. Polymers. 2019;5:1-11. http://dx.doi.org/10.3390/polym11030505.

10. CNR: Advisory Committee on Technical Recommendations for Construction. CNR - DT 203. Guide for the design and construction of concrete structures reinforced with fiber-reinforced polymer Bars, Rome, Italy: National Research Council; 2006.

11. Zhu HG, Leung CKY, Kim JK, Liu MY. Degradation of glass fiber-reinforced plastic composites containing nanoclay in 
alkaline environment. J Compos Mater. 2011;45:2147-56. http://dx.doi.org/10.1177/0021998311401064.

12. Khennane A, Melchers RE. Durability of glass polymer composites subject to stress corrosion. J Compos Mater. 2003;7:109-17. http://dx.doi.org/10.1061/(ASCE)1090-0268(2003)7:2(109).

13. Micelli F, Corradi M, Aiello MA, Borri A. Properties of aged GFRP reinforcement grids relared to fatigue life and alkaline environment. Appl Sci. 2017;7:1-13. http://dx.doi.org/10.3390/ app.7090897.

14. Sawpan MA. Effect of alkaline conditioning and temperature on the properties of glass fiber polymer composite bar. Polym Compos. 2016;38:96-104. http://dx.doi.org/10.1002/pc.23516.

15. Ali AH, Benmokrane B, Mahamed HM, Manalo A, El-Safty A. Statistical analysis and theorical predictions of the tensilestrength retention of glass fiber-reinforced polymer bars based on resin type. J Compos Mater. 2018;52:2929-48. http://dx.doi. org $/ 10.1177 / 0021998318755866$.

16. Benmokrane B, Ali AH, Mohamed HM, Elsafty A, Manalo A. Laboratory assessment and durability performance of vinyl-ester, polyester, and epoxy glass-FRP bars for concrete structures. Compos, Part B Eng. 2017;114:163-74. http://dx.doi. org/10.1016/j.compositesb.2017.02.002.

17. ACI: American Concrete Institute. ACI 440.3R-15. Guide test methods for fiber-reinforced polymers (FRPs) for reinforcing or strengthening concrete structures. Farmington Hills, USA: American Concrete Institute; 2015.

18. FIB: International Federation for Structural Concrete. FRP reinforcement in RC structures. Switzerland: FIB; 2007.

19. Portnov G, Bakis CE, Lackey E, Kulakov V. FRP reinforced bars - designs and methods of manufacture. Mech Compos Mater. 2013;49:381-400. http://dx.doi.org/10.1007/s11029013-9355-1.

20. American Society for Testing and Materials. Standard test methods for density and specific gravity of plastics by displacement ASTM D792. West Conshohocken: ASTM International; 2020.

21. American Society for Testing and Materials. Standard test methods for constituent content of composite materials - ASTM D3171. West Conshohocken: ASTM International; 2015.

22. American Society for Testing and Materials. Standard test methods for tensile properties matrix composite materials ASTM D7205. West Conshohocken: ASTM International; 2016.

23. American Society for Testing and Materials. Standard test method for Alkali resistance of Fiber Reinforced Polymer (FRP) matrix composite bars used in concrete construction - ASTM D7705. West Conshohocken: ASTM International; 2019.

24. American Society for Testing and Materials. Standard test method for water absorption of plastics - ASTM D570. West Conshohocken: ASTM International; 2018.

25. Micelli F, Nanni A. Durability of FRP rods for concrete structures. Constr Build Mater. 2004;18:491-503. http://dx.doi. org/10.1016/j.conbuildmat.2004.04.012.

26. Won JP, Yoon YN, Hong BT, Choi TJ, Lee SJ. Durability characteristics of nano-GFRP composites reinforcing bars for concrete structures in moist and alkaline environments. Compos Struct. 2012;94:1236-42. http://dx.doi.org/10.1016/j. compstruct.2011.11.006.

27. Duncan C, Broughton WR. Absorption and diffusion of moisture in polymeric materials. Teddington: National Physical Laboratory of United Kingdom; 2007. 63 p. (102).

28. American Society for Testing and Materials. Standard test methods for assignment of the glass transition temperatures by differential scanning calorimetry - ASTM E1356. West Conshohocken: ASTM International; 2008.

29. Pansart S. Prepreg processing of advanced fibre-reinforced polymer (FRP) composites. In: Bai J, editor. Advanced Fibre-Reinforced Polymer (FRP) Composites for Structural
Applications. Sawston: Woodhead Publishing; 2013. https:// doi.org/10.1533/9780857098641.2.125

30. Gooranorimi O, Suaris W, Dauer E, Nanni A. Microstructural investigation of glass fiber reinforced polymer bars. Compos, Part B Eng. 2017;110:338-95. http://dx.doi.org/10.1016/j. compositesb.2016.11.029.

31. Chen Y, Davalos JF, Ray I, Kim HY. Accelerated aging tests for evaluations of durability performance of FRP reinforcing bars for concrete structures. Compos Struct. 2007;78:101-11. http://dx.doi.org/10.1016/j.compstruct.2005.08.015.

32. Padmavathi SV, Karbhari M. Hygrothermal effects on durability and moisture kinetics of fiber-reinforced polymer composites. (No. FHWA/CA/ES-07/01). San Diego: California Department of Transportation/ Department of Structural Engineering; 2006.

33. Apicela A, Migliaresi C, Nicolais L, Iaccarino L, Roccotelli S. The water ageing of unsaturated polyester-based composites: influence of resin chemical structure. Composites. 1983;14:38792. http://dx.doi.org/10.1016/0010-4361(83)90160-X.

34. Chin JW, Aouadi K, Haight MR, Hughes WL, Nguyen T. Effects of water, salt solution and simulated concrete pore solution on the properties of composite matrix resins used in civil engineering applications. Polym Compos. 2001;22:28297. http://dx.doi.org/10.1002/pc.10538.

35. Montaigu M, Robert M, Ahmed EA, Asce M, Benmokrane B. Laboratory characterization and evaluation of durability performance of new polyester and vinylester E-glass GFRP dowels for jointed concrete pavement. J Compos Constr. 2013;17:176-87. http://dx.doi.org/10.1061/(ASCE)CC.19435614.0000317.

36. Sawpan MA. Shear properties and durability of GFRP reinforcement bar aged in seawater. Polym Test. 2019;75:31220. http://dx.doi.org/10.1016/j.polymertesting.2019.02.033.

37. Chin JW, Nguyen T, Aouadi K. Sorption and diffusion of water, salt water, and concrete pore solution in composite matrices. $\mathrm{J}$ Appl Polym Sci. 1999;71(3):483-92. http://dx.doi.org/10.1002/ (SICI)1097-4628(19990118)71:3<483:AID-APP15>3.0.CO;2-S.

38. Arias JPM, Bernal C, Vazquez A, Escobar MM. Aging in water and in an alkaline medium of unsaturated polyester and epoxy resins: experimental study and modeling. Adv Polym Technol. 2018;37:459-60. http://dx.doi.org/10.1002/adv.21684.

39. Upadhyay PC, Mishra A. Modified one-dimensional fickean solution for moisture absorption in composites. J Reinf Plast Compos. 1990;9:335-45. http://dx.doi.org/10.1177/073168449000900402.

40. Sawpan MA, Mamun AA, Holdsworth PG. Long term durability of pultruded polymer composite bar in concrete environment. Mater Des. 2014;57:616-24. http://dx.doi.org/10.1016/j. matdes.2014.01.049.

41. Kamal ASM, Boulfiza M. Durability of GFRP rebars in simulated concrete solutions under accelerated aging conditions. J Compos Constr. 2011;15:473-81. http://dx.doi.org/10.1061/(ASCE) CC.1943-5614.0000168.

42. Li C, Xian G, Li H. Water absorption and distribution in a pultruded unidirectional carbon/glass hybrid rod under hydraulic pressure and elevated temperatures. Polymers. 2018;10:76-92. http://dx.doi.org/10.3390/polym10060627.

43 Chin JW, Nguyen T, Aouadi K. Effects of environmental exposure on Fiber-Reinforced Plastic (FRP) materials used in construction. Astm J Compos Technol Res. 1997;19(4):205-213. https://doi. org/10.1520/CTR10120J

44. Manalo A, Maranan G, Benmokrane B, Cousin P, Alajarmeh $\mathrm{O}$, Ferdous W, et al. Comparative durability of GFRP composite reinforcing bars in concrete and simulated concrete environments. Cement Concr Compos. 2020;109:1-14. http:// dx.doi.org/10.1016/j.cemconcomp.2020.103564.

45. Weitsman YJ. Fluid effects in polymers and polymeric composites. Boston: Springer; 2012

46. Cousin P, Hassan M, Vijay PV, Benmokrane B. Chemical resistance of carbon, basalt and glass fibers used in FRP 
reinforcing bars. J Compos Mater. 2019;53:3651-70. http:// dx.doi.org/10.1177/0021998319844306.

47. Micelli F, Aiello MA. Residual tensile strength of dry and impregnated fibres after exposure to alkaline environments. Compos, Part B Eng. 2019;159:490-501. http://dx.doi. org/10.1016/j.compositesb.2017.03.005.

48. Robert M, Benmokrane B. Combined effects of saline solution and moist concrete on long-term durability of GFRP reinforcing bars. Constr Build Mater. 2013;38:274-84. http://dx.doi. org/10.1016/j.conbuildmat.2012.08.021.
49. ACI: American Concrete Institute. ACI 440.1R-06. Guide for the design and construction of structural concrete reinforced with FRP bars. Farmington Hills: American Concrete Institute; 2006.

50. Wang Z, Zhao XL, Xian G, Wu G, Raman RKS, Al-Saad $\mathrm{S}$, et al. Long-term durability of basalt and glass fiber reinforced polymer (BFRP/GFRP) bars in seawater and sea sand concrete environment. Constr Build Mater. 2017;139:467-89. http:// dx.doi.org/10.1016/j.conbuildmat.2017.02.038. 